\title{
Responses of Antioxidant in Rainbow Trout Exposed to Temephos Veysel PARLAK $^{1^{*}} \quad$ Arzu UCAR $^{1} \quad$ Gonca ALAK $^{1} \quad$ Muhammed ATAMANALP $^{1}$
}

\begin{abstract}
In this study, rainbow trout was exposed to temephos (TE) during 96h acute toxicity conditions. The toxic compound was given in doses of $3 \mathrm{mg} \mathrm{L}^{-1}$ and $6 \mathrm{mg} \mathrm{L}^{-1}$. Furthermore, we assessment antioxidant enzymes activity (glucose-6-phosphate dehydrogenase (G6PD), catalase (CAT), glutathione reductase (GR), superoxide dismutase (SOD), malondialdehyde (MDA) level in liver and acetylcholinesterase (AChE) in brain. CAT, SOD, GR, G6PD, and MDA in liver were demonstrated significant effects by the treatments $(\mathrm{P}<0.05)$. TE exposure resulted in the inhibition of AChE activity, which, compared with the control group, decreased in all doses $(\mathrm{P}<0.05)$. The results showed that temephos inhibited liver tissue's enzyme activities and increased MDA levels. In the light of these data, we can say that temephos toxicity should be taken into consideration in aquatic environments.
\end{abstract}

Key words: Pesticide; oxidative stress; AChE; rainbow trout

\section{Temefos’a Maruz Kalan Gökkuşağı Alabalıklarında, Antioksidan Cevaplar}

ÖZET: Çalışmamızda gökkuşağı alabalıkları temefosun 3 ve $6 \mathrm{mg} \mathrm{L}^{-1}$ dozlarına akut uygulama ile maruz bırakılmıştır. Uygulama sonrasında karaciğer dokusunda antioksidan enzim aktiviteleri (Süperoksitdismutaz (SOD), katalaz (CAT), glutatyon redüktaz (GR), glukoz 6 fosfat dehidrogenaz (G6PD)), malondialdehit seviyesi ve beyin dokusunda asetilkolin esteraz (AChE) aktivitesi değerlendirildi. Karaciğer dokusunda SOD, CAT, GR, G6PD aktivitelerinde ve MDA seviyesinde önemli seviyede değişiklikler belirlendi $(\mathrm{P}<0.05)$. Kontrol grubu ile kıyaslandığı zaman tüm doz uygulanan gruplarda AChE aktivitesinin inhibe olduğu tespit edildi $(\mathrm{P}<0.05)$. Sonuçlar, temefosun karaciğer dokusunda enzim aktivitelerini inhibe ettiğini ve MDA seviyesini arttırdığını göstermiştir. $\mathrm{Bu}$ veriler 1şığında sucul ortamlarda temefos toksisitesinin dikkate alınması gerektiğini söyleyebiliriz.

Anahtar kelimeler: Pestisit; oksidatif stres; asetilkolinesreaz (AChE); gökkuşaği alabalığı

\footnotetext{
${ }^{1}$ Veysel PARLAK (Orcid ID: 0000-0002-3459-7963), Arzu UÇAR (Orcid ID: 0000-0001-5675-9401), Gonca ALAK (Orcid ID: 0000-0002-7539-1152), Muhammed ATAMANALP (Orcid ID: 0000-0002-2038-3921), Department of Aquaculture, Faculty of Fisheries, Atatürk University, Erzurum, Türkiye

* Sorumlu Yazar/Corresponding Author: Veysel PARLAK,, e-mail: veysel.parlak@atauni.edu.tr 


\section{INTRODUCTION}

Temephos (TE) one of the organophosphorus insecticides. It is mainly used as a larvicide to control mosquito in aquatic areas. The WHO Pesticides Evaluation Scheme suggests using TE as control agent in potable water sources (Anonymous, 2018). This pesticide, which is used intensively and unconsciously in agricultural areas in our country, is transported by rainfall and surface water and reaches to aquatic environments. Especially with increasing pesticide usage in the summer months there may be threats to aquatic organisms. In aquatic environments, trout, preferred as test organism, is found commonly in our fresh waters in our country.

As it is the case in other organophosphates, TE affects the central nervous system. Its rapid absorption and accumulation in tissues is due to its hydrophobicity (log Kow=4.91). AChE inhibition and antioxidant enzyme activities are the main biomarkers of exposure to certain organophosphates and carbamate insecticides in fish (Sandahl et al., 2005; Barbosa and Júnior, 2015). Some of the aquatic organisms, especially fish are used as biological indicators to monitor environmental pollution (Kiric1 et al., 2017). Furthermore, the biochemical parameters can contribute to the early detection of the substances that help monitor environmental quality (Barbosa and Júnior, 2015).

In this study we determined toxic effects of TE using antioxidant enzymes activity in rainbow trout.

\section{MATERIALS AND METHODS}

\section{Fish samples and experimental design}

Rainbow trout (Oncorhynchus mykiss) $(20 \pm 1.5 \mathrm{~g}, 16 \pm 2 \mathrm{~cm})$ samples were put in tanks with a flow rate of $0.5 \mathrm{~L}$ min per $\mathrm{kg}$ fish (minimum). The tanks (150 liter) had an average water temperature of $10 \pm 1.5{ }^{\circ} \mathrm{C}$. The dissolved oxygen concentration in the tanks was $9.2 \mathrm{mg} \mathrm{L}$ 1 and $\mathrm{pH}$ was 7.2. A total of 60 fish samples were distributed evenly across six tanks (each tank contained 10 fish samples). Of the tanks, two contained the control groups (A) and four contained the treatment groups. TE was procured from a company (Sigma) and its stock solution was dissolved in water. The $\mathrm{LC}_{50}$ value of TE for rainbow trout is $9.8 \mathrm{ppm}$ (Anonymous, 2018). In the present study TE concentrations of $3 \mathrm{mg} \mathrm{L}^{-1}$ (B) and $6 \mathrm{mg} \mathrm{L}^{-1}$ (C) $(30 \%$ and $60 \%$ concentrations of $\mathrm{LC}_{50}$ value) were deemed suitable for use in the treatments. Excluding two control tanks (no pesticide application), $3 \mathrm{mg} \mathrm{L}^{-1}$ and $6 \mathrm{mg} \mathrm{L}^{-1} \mathrm{TE}$ was added to four tanks, respectively. The concentrations of tanks were reapplied every 12 hours for readjusting the dose.

\section{Tissue homogenates}

Immediately after cervical dislocation to euthanize the samples, the dissection procedure was performed (Botté et al., 2012). The liver and brain hemolysates were prepared using a modificated method described by Kirıci et al., (2017). The samples were homogenized (1\% v v) in a 0.1 M Triton X 100 containing phosphate buffer ( $\mathrm{pH}$ 7.4). The supernatants obtained with the centrifugation of the liver homogenates at 13 $000 \mathrm{rpm}$ for $60 \mathrm{~min}\left(4^{\circ} \mathrm{C}\right)$ were used as the enzyme source to estimate enzyme activities and malondialdehyde (MDA) levels. The brain homogenates were centrifuged at $13000 \mathrm{rpm}$ for $30 \mathrm{~min}\left(4^{\circ} \mathrm{C}\right)$ and supernatants were used as the enzyme source to estimate the AChE activity (Parlak, 2018).

\section{Determination of the antioxidant enzyme activities and MDA level}

Catalase (CAT) activity was measured using the Aebi method (1974) which is based on the $\mathrm{H}_{2} \mathrm{O}_{2}$ consumption-induced decrease in absorbance at $240 \mathrm{~nm}$. The reaction mixture contained potassium phosphate and $\mathrm{H}_{2} \mathrm{O}_{2}$. The superoxide dismutase (SOD) activity was 
determined using the method described by Sun et al., (1988), in which the inhibitory effect of SOD on nitro blue tetrazolium (NBT) reduction is used and the reduction of NBT to blue formazan by the superoxide anion is measured at $560 \mathrm{~nm}$. As described by Beutler (1984), the levels of NADPH and GSSG were used to determine glutathione reductase (GR) activity. One unit of GR was defined as the consumed NADPH quantity that catalyze the reduction of 1 mM GSSG per min. The glucose 6 phosphate dehydrogenase (G6PD) activity was analyzed at $340 \mathrm{~nm}$ in a spectrophotometer according to Beutler (1984). Malondialdehyde is a secondary product of the MDA lipid peroxidation. The measurement is carried out by measuring the absorbance of the pink complex at $532 \mathrm{~nm}$, which is formed due to the incubation of MDA with thiobarbituric aside (TBA) at $95^{\circ} \mathrm{C}$ (Luo et al., 2006). Spectrophotometry was used to determine each sample's protein levels at a wavelength of $595 \mathrm{~nm}$ and the results were recorded by taking the BSA as the standard (Bradford, 1976).

\section{AChE activity}

The reaction mixture contained $10 \mathrm{mM}$ acetylthiocholine iodide, $0.5 \mathrm{mM}$ DTNB in $1 \%$ sodium citrate, $0.5 \mathrm{M}$ phosphate buffer
$\left(\mathrm{KH}_{2} \mathrm{PO}_{4} ; \mathrm{pH} 8\right)$, and water. The reaction was catalyzed using a crude enzyme extract and the alteration in absorbance at $412 \mathrm{~nm}$ was measured for 5 min (Sandahl et al., 2005; Parlak, 2018).

\section{Statistical analysis}

The statistical analyses of the results were performed using the SPSS 20.0 software package. To determine the significantly different results, one-way ANOVA was used. Duncan test was used to detect the differences between the groups. The data were expressed as the mean \pm SEM. Significance level was determined at $\mathrm{P} \leq 0.05$.

\section{RESULTS AND DISCUSSIONS}

These study findings showed that, at the end of the 96 th, exposure to TE in Oncorhynchus mykiss caused a significant decrease in activities of antioxidant enzymes in the treatment groups $(\mathrm{B}, \mathrm{C})$ compared with the non-exposure group (A: control). At the end of the $96 \mathrm{~h}$ acute exposure, the activity of the antioxidant enzymes in liver tissues decreased with the increasing concentrations of TE. In contrast, the MDA content in the tissues increased after TE exposure (Table 1).

Table 1. The effect of different concentrations of TE on antioxidant enzyme activities and MDA levels of rainbow trout (Oncorhynchus mykiss) liver (Mean \pm SEM)

\begin{tabular}{ccccccc}
\hline Tissue & Treatment & CAT & SOD & GR & G6PD & MDA \\
\hline Liver* $^{\text {A }}$ & $0.77 \pm 0.06^{\mathrm{a}}$ & $0.08 \pm 0.01^{\mathrm{a}}$ & $0.07 \pm 0.01^{\mathrm{ab}}$ & $0.07 \pm 0.01^{\mathrm{a}}$ & $0.07 \pm 0.01^{\mathrm{b}}$ \\
& B & $0.56 \pm 0.06^{\mathrm{b}}$ & $0.03 \pm 0.01^{\mathrm{b}}$ & $0.10 \pm 0.01^{\mathrm{a}}$ & $0.06 \pm 0.01^{\mathrm{a}}$ & $0.12 \pm 0.01^{\mathrm{a}}$ \\
& C & $0.31 \pm 0.06^{\mathrm{c}}$ & $0.02 \pm 0.01^{\mathrm{b}}$ & $0.06 \pm 0.01^{\mathrm{b}}$ & $0.03 \pm 0.01^{\mathrm{b}}$ & $0.16 \pm 0.01^{\mathrm{a}}$
\end{tabular}

Lowercase superscripts $(a, b)$ indicate significant differences among different concentration within each experimental treatment group and tissue, whereas superscripts in uppercase show significant differences among dosage. Each value is the mean \pm SEM. of ten individual observations. For TE concentrations A: Control (no treatment), B: $3 \mathrm{mg} \mathrm{L}^{-1}$, and C: $6 \mathrm{mg} \mathrm{L}^{-1} * \mathrm{P}<0.05$ Enzyme specific activity (EU mg), MDA Specific activity (nmol ml.)

In the present study, exposure to TE caused a raise in the MDA levels in rainbow trout liver tissues, which suggests that the TE in applied concentrations increased the peroxidative tissue 
damage. Lipid peroxidation can be the first step of organophosphate-induced cellular membrane damage. The increase in MDA indicated that the damage caused by ROS was potentially an important toxic effect of TE (Kavitha and Rao, 2008; Narr, 2014).

Many organisms have systems to protect themselves against the activated ROS damaging effects (Xing et al., 2012). The liver's SOD and CAT activities decreased in all treatment groups with exposure to TE, in the present study. The decreases in SOD and CAT activities is attributable to the inhibition of the formation of superoxide radicals (Parlak, 2018). The results obtained in this study for the related parameters agree with the results obtained in other studies (Oruç et al., 2004; Peixoto et al., 2006; Xing et al., 2012; Narr, 2014). We believe that the decrease in the SOD enzyme activity is due to the increase in the reactive oxygen species (ROS), which are formed due to pesticide exposure. SOD activity decrease was probably caused by superoxide anion radical, which, after transformation to $\mathrm{H}_{2} \mathrm{O}_{2}$, causes the oxidation of SOD (Rahal et al., 2014). TE application caused a decrease in the CAT specific activity and compared with the control group, relatively lower values were obtained (Table 1). The statistical analysis showed that the differences among all groups were significant $(\mathrm{P}<0.05)$. The inhibitory and inducing effects of pesticides on CAT were investigated in previous studies. Peixoto et al., (2006) reported that CAT activity was inhibited and induced when exposed to certain pollutants and concluded that it was not suitable for use as a biomarker in toxicology studies (Jeon et al., 2015). The decrease in the CAT activity in the present study agree with the results obtained by exposing different fish species to different pesticides (Nwani et al., 2010; Hattab et al., 2015). The results indicate that TE lipid peroxidation is accompanied by simultaneous decreases in the activities of antioxidant enzymes such as CAT and SOD. Antioxidant enzymes decrease results in increased oxidative stress. This indicates that free radicals are generated excessively when exposed to pesticides, which leads to the disruption of the antioxidant defense system (Zhu et al., 2014). Glutathione redox level, antioxidant enzyme activities, and lipid peroxidation are the main biomarkers used in toxicology studies (Kaviraj et al., 2014). Especially, the intracellular changes at GSH level are viewed as one of the most important indicators of the oxidative stress caused by the pollutants in fish (Zhang et al., 2004). In this study, GR and G6PD activities in liver were inhibited by $\mathrm{TE}$ exposure $(\mathrm{P}<0.05)$.

The GR and G6PD activities decreased in all tissues, especially in Group C. There are a large number of studies focusing on the relationships between pesticides and antioxidant activities of GR and G6PD in different species (Güler et al., 2013; Lavarías and Garcia, 2015). However, the number of the studies focusing on the oxidative stress caused by TE is limited. In this study, after the application of a B and C concentration of TE, a decrease was determined in GR and G6PD activities. These changes suggest that certain substances such as pesticides affect $\mathrm{O}_{2}$ production and have inhibitory effects on enzyme activity (Jin et al., 2015; Ucar et al., 2017). However, the decrease in GSH levels due to TE exposure may have been caused by the increase in GSH utilization. GSH is converted into oxidized glutathione and results in the efficient regeneration of GSH (Yonar, 2013). The decrease in GR activity was attributed to the increased production of oxidized glutathione (GSSG). Studies have shown that different species may use different mechanisms to cope with pesticide exposure (Parlak, 2018).

After $96 \mathrm{~h}$ acute exposure, the activity of $\mathrm{AChE}$ in brain decreased with the increasing concentrations TE. In some species, AChE 
showed tissue-specific sensitivity and the enzymes caused dose and time-dependent inhibition while the rate of inhibition differed depending on the species and age (Ramsay and
Tipton, 2017). In the present study, TE resulted in the inhibition of the $\mathrm{AChE}$ activity in brain (Table 2).

Table 2. The effect of different concentrations of TE on AChE enzyme activities of rainbow trout (Oncorhynchus mykiss) brain (Mean \pm SEM)

\begin{tabular}{rcc}
\hline Tissue & Treatment & AChE \\
\hline & A & $0.040 \pm 0.03^{\mathrm{a}}$ \\
Brain* & B & $0.020 \pm 0.03^{\mathrm{b}}$ \\
& C & $0.013 \pm 0.03^{\mathrm{b}}$
\end{tabular}

Lowercase superscripts (a, b) indicate significant differences among different concentration within each experimental treatment group, whereas superscripts in uppercase show significant differences among dosage. Each value is the mean \pm SEM. of twenty individual observations. For TE concentrations A: Control (no treatment), B: $3 \mathrm{mg} \mathrm{L}^{-1}$, and C: $6 \mathrm{mg} \mathrm{L}^{-1} *$ $\mathrm{P}<0.05$ AChE Specific activity (EU mg).

In addition, the AChE activity was reduced compared with the control samples. The activity of AChE was evidently affected by the concentration of TE in all treated fish samples. The results of the study showed that the AChE activity in the $96 \mathrm{~h}$ TE exposed juvenile rainbow trout samples was significantly inhibited and it continued to decrease depending on TE concentration. In the control fish samples, the AChE activity in brain was higher than that of the treatment groups. AChE was present in the brain tissue of trout at the lowest TE concentration $\left(3 \mathrm{mg} \mathrm{L}^{-1}\right)$ and the enzyme activity in brain is sensitive to the inhibitory effects of TE. There are a large number of studies focusing on the connection between pesticides, organophosphates, and AChE activity in different species (Tam et al., 2015; Petrov et al., 2018). However, there is no study focusing on the relationship between TE and AChE activity in fish.

\section{CONCLUSION}

To establish regulatory measures, data obtained for acute toxicity have been used to develop water quality guidelines (Nwani et al., 2010). The results of the study revealed that TE negatively affected antioxidant enzyme activity and AChE activity. Acute exposure to TE caused changes enzyme activity and MDA contents in liver of rainbow trout. Furthermore, the results revealed that oxidative parameters, and AChE were significantly changed in the TE exposed rainbow trout samples. To the best of our knowledge, this is the first study reporting the acute effects of TE on rainbow trout. Although there are previous studies which can compared with our results, none of these studies focused on the toxic effects of TE on fish. Thus, the information presented in this study can contribute to the elucidation of the toxicant response of fish to TE exposure and serve as a substantial reference for future studies. More investigations are required to elaborate the mechanism of TE toxicity.

\section{REFERENCES}

Abdussalam MD, Shahjahan MD, Sadia S, Farhana H, Khalilur R, 2015. Effects of Sublethal Doses of an Organophosphorus Insecticide Sumithion on Some Hematological Parameters in Common Carp, Cyprinus carpio. Pakistan Journal of Zooloji, 47(5): 1487-1491. 
Adhikari S, Sarkar B, Chatterjee A, Mahapatra CT, Ayyappan S, 2004. Effects of Cypermethrin and Carbofuran Haematological Parameters and Prediction of Their Recovery in a Freshwater Teleost, Labeo rohita (Hamilton). Ecotoxicology Environmental Safety, 58: 220 226.

Aebi H, 1974. Methods of Enzymatic Analysis, Catalase, In: Bergmeyer H.U. (ed). Academic Press, New York, 682 p.

Anonymous, (2018). Temephos in Drinking Water: Use for Vector Control in Drinking- Water Sources and Containers. Background Document for Development of WHO Guidelines for Drinking-Water Quality. WHO, Geneva:

http://www.who.int/water_sanitation_health/d wq/chemicals/temephos.pdf (Date of accessed 17.09.18).

Barbosa PB, Júnior EOC, 2015. Enzymatic Alterations and Genotoxic Effects Produced by Sublethal Concentrations of Organophosphorous Temephos in Poecilia reticulata. Journal of Toxicology and Environmental Health, Part A, 78: 1033-1037.

Beutler E, 1984. A Manual of Biochemical Methods, Red Cell Metabolism: second ed., Grune and Starton, NewYork, 160 p.

Botté ES, Jerry DR, Codi KS, Smith-Keune C, Negri AP, 2012. Effects of Chlorpyrifos on Cholinesterase Activity and Stress Markers in the Tropical Reef Fish Acanthochromis polyacanthus. Marine Pollution Bulletin, 65: 384-393.

Bradford MM, 1976. A Rapid and Sensitive Method for the Quantitation of Microgram Quantities of Protein Utilizing the Principle of Protein dye Binding, Analytical Biochemistry. 72: 248-254.

Güler M, Kivanc MR, Türkoglu V, Basi Z, Kivrak H, 2013. In Vitro Determination of G6PD Enzyme Activitypurified from Lake Van Fish (Chalcalburnus tarichii Pallas, 1811) Liver Exposed to Pesticides. Bulletin Environmental Contamination Toxicology, 91 (5): 560-564.
Hattab S, Boughattas I, Boussetta H, Viarengo A, Banni M, Sforzini S, 2015. Transcriptional Expression Levels and Biochemical Markers of Oxidative Stres in the Earth Worm Eisenia and Rei after Exposure to 2,4dichlorophenoxyaceticacid(2,4-D).

Ecotoxicology and Environmental Safety, 122: 76-82.

Jeon HJ, Lee Y, Mo H, Kim M, Al-Wabel MI, Kim Y, Cho K, Kim T, Ok YS, Lee S, 2015. Chlorpyrifos-Induced Biomarkers in Japanese Medaka (Oryzias latipes). Environmental Science and Pollution Research. 23(2): 10711080.

Jin Y, Liu Z, Peng T, Fu Z, 2015. The Toxicity of Chlorpyrifos on the Early Life stage of Zebrafish: A survey on the Endpoints at Development, Locomotor Behavior, Oxidative Stress and Immunotoxicity, Fish\& Shellfish Immunology, 43: 405-414.

Kaviraj A, Unlu E, Gupta A, El Nemr A, 2014. Biomarkers of Environmental Pollutants. Biomedical Research. 806598.

Kavitha P, Rao JV, 2008. Toxic Effects of Chlorpyrifos on Antioxidant Enzymes and Target Enzyme Acetylcholinesterase Interaction in Mosquito Fish, Gambusia affinis. Environmental Toxicology Pharmacology, 26: 192-198.

Kırıcı M, Turk C, Caglayan C, Kırıcı M, 2017. Toxic Effects of Copper Sulphate Pentahydrate on Antioxidant Enzyme Activities and Lipid Peroxidation of Freshwater Fish Capoeta Umbla (Heckel, 1843) Tissues. Applied Ecology and Environmental Research 15(3): 1685-1696.

Köprücü SS, Köprücü K, Ural MS, Ispir Ü, Pala M, 2006. Acute Toxicity of Organophosphorous Pesticide Diazinon and its Effects on Behavior and some Hematological Parameters of Fingerling European Catfish (Silurus glanis L.), Pesticide Biochemistry and Physiology, 86: 99-105. 
Kumar S, Lata S, Gopal K, 1999. Deltamethrin Induced Physiological Changes in Freshwater Catfish Heterop neustes fossilis. Bulletin Environmental Contamination Toxicology, 62: 254-258.

Lavarías S, García CF, 2015. Acute Toxicity of Organophosphate Fenitrothion on Biomarkers in Prawn Palaemonetes Argentinus (Crustacea: Palaemonidae). Environmental Monitoring and Assessment, 187: 65.

Luo Y, Su Y, Lin RZ, Shi HH, Wang XR, 2006. 2chlorophenol Induced ROS Generation in fish Carassius auratus Based on the EPR Method, Chemosphere, 65(6): 1064-1073.

Narr MR, 2014. Tissue-Specific Recovery of Oxidative and Antioxidant Effects of Chlorpyrifos in the Freshwater Crab, Barytelphusa guerini, Archives of Environmental Contamination and Toxicology, 67: 158-166.

Nwani CD, Lakra WS, Nagpure NS, Kumar R, Kushwaha B, Srivastava SK, 2010. Toxicity of the Herbicide Atrazine: Effects on Lipid Peroxidation and Activities of Antioxidant Enzymes in the Freshwater Fish Channa punctatus (Bloch). International Journal of Environmental Research and Public Health, 7(8); 3298-3312.

Oruç EÖ, Sevgiler Y, Uner N, 2004. Tissue-specific Oxidative Stress Responses in Fish Exposed to 2,4-D and Azinphosmethyl. Comparative Biochemistry and Physiology Part C, 137: 4351.

Parlak V, 2018. Evaluation of Apoptosis, Oxidative Stress Responses, AChE Activity and Body Malformations in Zebrafish (Danio rerio) Embryos Exposed to Deltamethrin. Chemosphere, 207: 397-403.

Peixoto F, Alves-Fernandes D, Santos, D, Fontaínhasfernandes A, 2006. Toxicological Effects of Oxyfluorfen on Oxidative Stress Enzymes in Tilapia Oreochromis niloticus. Pesticide Biochemistry and Physiology, 85: 91-96.
Petrov KA, Kharlamova AD, Lenina OA, Nurtdinov AR, Sitdykova ME, Ilyin VI, Zueva IV, Nikolsky EE, 2018. Specific Inhibition of Acetylcholinesterase as an Approach to Decrease Muscarinic side Effects during Myasthenia Gravis Treatment. Science Report. 10; 8(1): 304.

Rahal A, Kumar A, Singh V, Yadav B, Tiwari R, Chakraborty S, Dhama K, 2014. Oxidative Stress, Prooxidants, and Antioxidants: the Interplay. Biomedical Research, 2014:761264.

Ramsay RR, Tipton KF, 2017. Assessment of Enzyme Inhibition: a Review with Examples from the Development of Monoamine Oxidase and Cholinesterase Inhibitory Drugs. Molecules, 22 (2017): 1-46.

Sandahl JF, Baldwin DH, Jenkins JJ, Scholz NL, 2005. Comparative Thres Holds for Acetylcholinesterase Inhibition and Behavioral Impairment in Coho Salmon Exposed to Chlorpyrifos. Environmental Toxicology and Chemistry. 24(1): 136-145.

Saravanan M, Kumar K, Ramesh M, 2011. Haematological and Biochemical Responses of Freshwater Teleost Fish Cyprinus carpio (Actinopterygii: Cypriniformes) During Acute and Chronic Sublethal Exposure to Lindane. Pesticide Biochemistry and Physiology, 100: 206-211.

Sun Y, Oberley LW, Li Y, 1988. A Simple Method for Clinical Assay of Superoxide Dismutase, Clinical Chemistry, 34(3): 497-500.

Tam NT, Berg H, Tuyen PTB, Cong NV, 2015. Effect of Chlorpyrifos Ethyl on Acetylcholinesterase Activity in Climbing Perch (Anabas testudineus, Bloch, 1972). Archives of Environmental Contamination and Toxicology, 69: 515-524.

Van der Oost R, Beyer J, Vermeulen NPE, 2003. Fish Bioaccumulation and Biomarkers in Environmental Risk Assessment: a Review. Environmental Toxicology and Pharmacology, 13: 57-149. 
Xing H, Wang X, Sun G, Gao X, Xu S, 2012. Effects of atrazine and chlorpyrifos on activity and transcription of glutathione S-transferase in Common Carp (Cyprinus carpio L.), Environmental Toxicology and Pharmacology. 33: $233-244$.

Yonar SM, 2013. Toxic Effects of Malathionin Carp, Cyprinus carpio carpio: Protective Role of Lycopene, Ecotoxicology and Environmental Safety, 97: 223-229.
Zhang JF, Shen H, Wang XR, Wu JC, Xue YQ, 2004. Effects of Water-soluble Fractions of Diesel Oil on Theantioxidant Defenses of Goldfish, Crassius auratus. Ecotoxicology Environmental Safety, 58: 110-116.

Zhu B, Gong YX, Liu L, Li DL, Wang Y, Ling F, Wang G, 2014. Toxic Effects of Triazophos on Rare Minnow (Gobiocypris rarus) Embryos and Larvae. Chemosphere, 108: 46-54. 